\title{
TOXOPLASMOSIS-RELATED KNOWLEDGE AMONG PREGNANT AND POSTPARTUM WOMEN ATTENDED IN PUBLIC HEALTH UNITS IN NITERÓI, RIO DE JANEIRO, BRAZIL
}

Patricia Riddell MILlAR(1,2), Fernanda Loureiro de MOURA(1,2), Otílio Machado Pereira BASTOS(1), Danuza Pinheiro Bastos Garcia de MATTOS(1), Ana Beatriz Monteiro FONSECA(3), Adriana Pittella SUDRÉ(1), Daniela LELES(1) \& Maria Regina Reis Amendoeira(2)

\begin{abstract}
SUMMARY
The present study conducted a toxoplasmosis-related knowledge level survey with 400 pregnant and puerperal women attended in public health units in the municipality of Niterói, Rio de Janeiro. Only 111 (27.8\%) women claimed to know about the disease. Most of them $(\mathrm{n}=289 ; 72.2 \%)$ had never heard about toxoplasmosis nor knew how to prevent the infection by Toxoplasma gondii. A significant difference $(p=0.013)$ regarding the presence of anti-T. gondii IgG was observed between women who claimed to know about the disease and those who had never heard about it. These results highlight the importance of a systematic serological screening process for toxoplasmosis, as well as the importance of primary prevention by accurate information during prenatal care, an important Public Health action to be implemented.
\end{abstract}

KEYWORDS: Toxoplasmosis; Pregnant women; Knowledge; Primary prevention.

\section{INTRODUCTION}

Toxoplasmosis is a parasitic infection caused by protozoan Toxoplasma gondii (T. gondii). T. gondii is a facultative heteroxenous parasite, intracellular obligatory, found in different species of vertebrates, including humans ${ }^{11,27}$. In felids, its definitive hosts, the parasite reproduces asexually and sexually, while in its intermediate hosts (birds and mammals), the parasite only reproduces asexually.

Transmission varies according to several factors, such as the environment, nutrition, and cultural habits ${ }^{12}$. Susceptible humans can be infected by $T$. gondii through ingestion of bradyzoites in raw or undercooked meat and other animal products ${ }^{6,25}$; contact with feces of domestic felids or soil contaminated with sporulated oocysts ${ }^{10,15}$; ingestion of sporulated oocysts contaminating water ${ }^{7,3}$, fruits and vegetables ${ }^{2,34}$; and also by tachyzoites transmitted through placenta, blood transfusion, and organ transplant ${ }^{22,27}$.

T. gondii can cause a congenital infection when women are infected during pregnancy ${ }^{35}$, or less commonly when chronic infections become disseminated due to immune-compromising ${ }^{32}$ or reinfections ${ }^{16,20}$. Studies reported that most infected women are asymptomatic ${ }^{28}$. If congenital toxoplasmosis is not treated, severe or fatal sequelae can occur $^{21}$. Fetal transmission rates depend on three concomitant factors: maternal parasitemia, gestational age at infection, and maternal immune response to $T$. gondii ${ }^{37}$.
The most frequently observed clinical signs of congenital toxoplasmosis are premature birth, low birth weight, retinocoroiditis, squint, jaundice, cerebral calcifications, hydrocephalus, and hepatosplenomegaly ${ }^{5}$.

There are very few reports of prenatal screening in Brazil ${ }^{14}$. Moreover, most of the studies were based on selected sampling, because there is no national screening of women or children for toxoplasmosis in the country. Studies on pregnant women reported anti-T.gondii IgG occurrence ranging from $31 \%$, in Rio Grande do $\mathrm{Sul}^{17}$, to $91.6 \%$, in Mato Grosso do $\mathrm{Sul}^{13}$ (two different states in Brazil). The risks of fetal infection are directly associated with disease prevalence in the population, and with the number of women in fertile age not infected and susceptible to infection during pregnancy ${ }^{23}$. Thus, the importance of preventive actions should be emphasized, as well as the early diagnosis and treatment, to prevent or attenuate fetal infection ${ }^{4,9,18,24,31,36}$.

A previous survey of pregnant and postpartum women in the same population in Niterói ${ }^{29}$ showed that a significant number $(41.5 \%)$ of susceptible women can acquire Toxoplasma gondii during pregnancy. These susceptible patients are at risk of transmitting the parasite to their offspring through vertical transmission.

Congenital toxoplasmosis prevention can be performed at primary, secondary, and tertiary levels ${ }^{1}$. Primary prevention is characterized by educational programs and Public Health ${ }^{19}$. Secondary prevention 


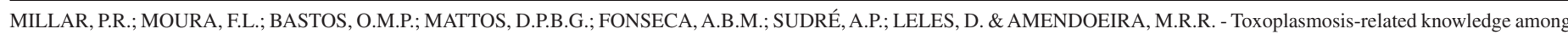
pregnant and postpartum women attended in public health units in Niterói, Rio de Janeiro, Brazil. Rev. Inst. Med. Trop. Sao Paulo, 56(5): 433-8, 2014.

consists of serological screening procedures during prenatal care to detect and treat acute infections by $T$. gondii, thus reducing the sequelae caused by congenital toxoplasmosis ${ }^{19}$. Tertiary prevention is focused on the newborn, in which newborns with subclinical congenital toxoplasmosis are treated in order to prevent further complications, especially ocular and risks of reactivation ${ }^{26}$.

The present study surveyed pregnant and puerperal women who attended public health units in the municipality of Niterói, Rio de Janeiro, in order to assess their toxoplasmosis-related knowledge level. Questions in the survey focused on infection pathways and disease prevention.

\section{MATERIAL AND METHODS}

A cross-sectional survey was given to pregnant $(n=276)$ and puerperal $(n=124)$ women from September 2010 to September 2011. All women signed the Free and Informed Consent term, according to resolution No. 196/96 of the National Health Council. The women were interviewed using a survey made up of multiple choice questions regarding transmission, symptoms, prevention, vertical transmission, diagnosis, and treatment of Toxoplasma gondii. Personal information (age and educational level) of the pregnant women were also collected. After the interview, a brochure with information about toxoplasmosis and prevention of this zoonosis was given to each woman. All women had already been subjected to serological tests for toxoplasmosis in a previous study ${ }^{29}$, where $\operatorname{IgG}$ and $\operatorname{IgM}$ anti- $T$. gondii antibodies were analyzed using an indirect fluorescent antibody test (IFAT) with a cutoff point of 1:16; and ELISA (BioKit ${ }^{\circledR}$, Barcelona, Spain), in which readings at or above the cutoff value were considered positive.

Participants were selected by convenience sampling. Postpartum women between the first and tenth day postpartum and pregnant women at any gestational age were eligible. On the other hand, women who did not agree to sign the consent statement were excluded from the analysis.

The questionnaires guided the face-to-face interviews conducted by the researchers, who provided guidance about the proposed research and read the consent form out loud, which the interviewees then signed. The questions were answered orally by the interviewees and recorded by the researchers, in order to facilitate the understanding of the subject matter. As the participant's name was written on the questionnaire, the risk of interviewing the same person twice was eliminated.

This study was conducted in the municipality of Niterói, located in Rio de Janeiro State. This municipality is considered of medium size $\left(133 \mathrm{~km}^{2}\right.$ of territorial extension) with approximately 489,562 inhabitants, and an urbanization index of $100 \%$. The urban growth setting is unequal, and neighborhoods of high and medium classes coexist alongside slums, where households exhibit poor health and sanitation conditions, with a low-income population.

Data were collected at a maternity and prenatal ambulatory of the Antônio Pedro University Hospital of the Fluminense Federal University; at the Viradouro, Souza Soares, Palácio and Preventório I and II units of the "Programa Médico de Família" (Family Doctor Program); and at the "Policlínica Comunitária Sérgio Arouca" (Sérgio
Arouca Community Polyclinic) of the Municipal Health Foundation of Niterói.

The Antônio Pedro University Hospital is a referral hospital for high-risk pregnancy, and receives patients living in Niterói, as well as in other neighboring cities, such as São Gonçalo, Maricá and Itaboraí. Units of the "Programa Médico de Família" as well as the "Policlínica Comunitária Sérgio Arouca" provide prenatal care for low-risk patients who live in specified regions of Niterói. Hence, each unit has its own area of activity and number of registered families. The people who use these services are characterized mostly by low educational level, financial difficulties, and lack of adequate sanitary conditions.

Statistical analyses were performed using the Chi-square test and the exact Fisher test. A $p$ value below 0.05 was considered significant. Data were analyzed using the software SPSS 10.0 (Statistical Package for the Social Sciences).

The present study was approved by the Ethics Committee for Research on Human Beings of the Fluminense Federal University and Antônio Pedro University Hospital (CAAE number 0059.0.258.00010), in accordance with Resolution $196 / 96$ of the National Health Council.

\section{RESULTS}

Out of the 400 completed questionnaires, $276(69 \%)$ were answered by pregnant and 124 (31\%) by postpartum women. Regarding the knowledge about toxoplasmosis, only $111(27.8 \%)$ women claimed to know about the disease. Most of them $(n=289 ; 72.2 \%)$ had never heard about toxoplasmosis nor knew how to prevent the infection by Toxoplasma gondii. The presence of IgG anti-T.gondii was significantly different between patients who knew about toxoplasmosis and those who did not (Table 1). There was no significant difference between the knowledge about toxoplasmosis and the location where data were collected (Table 2).

Table 1

Distribution of pregnant and postpartum women referred to public health units of Niterói-RJ, Brazil, according to toxoplasmosis knowledge and presence of anti-Toxoplasma gondii IgG antibodies, 2010-2011

\begin{tabular}{lcccc}
\hline Variables & $\begin{array}{c}\text { Reagents } \\
\mathbf{n}(\%)\end{array}$ & $\begin{array}{c}\text { Not reagents } \\
\mathbf{n}(\%)\end{array}$ & $\begin{array}{c}\text { Total } \\
\mathbf{n}(\%)\end{array}$ & $\boldsymbol{p}$ \\
\hline Know about toxoplasmosis & & & \\
Yes & $54(48.6)$ & $57(51.4)$ & $111(100.0)$ & 0.013 \\
No & $180(62.3)$ & $109(37.7)$ & $289(100.0)$ & \\
\hline Total & $\mathbf{2 3 4 ( 5 8 . 5 )}$ & $\mathbf{1 6 6 ( 4 1 . 5 )}$ & $\mathbf{4 0 0 ( 1 0 0 . 0 )}$ & \\
\hline
\end{tabular}

IgG: Immunoglobilin G.

From all women who claimed to know about toxoplasmosis, $36.9 \%(41 / 111)$ correctly associated $T$. gondii transmission with the 


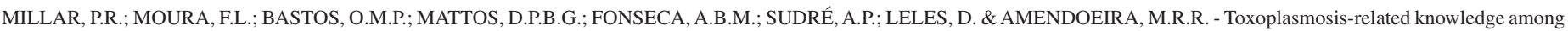
pregnant and postpartum women attended in public health units in Niterói, Rio de Janeiro, Brazil. Rev. Inst. Med. Trop. Sao Paulo, 56(5): $433-8,2014$.

Table 2

Distribution of pregnant and postpartum women referred to public health units of Niterói-RJ, Brazil, according to toxoplasmosis knowledge and sampling places

\begin{tabular}{lcccc}
\hline Variables & $\begin{array}{c}\text { Know } \\
\mathbf{n}(\boldsymbol{\%})\end{array}$ & $\begin{array}{c}\text { Do not know } \\
\mathbf{n}(\boldsymbol{\%})\end{array}$ & $\begin{array}{c}\text { Total } \\
\mathbf{n}(\boldsymbol{\%})\end{array}$ & $\boldsymbol{p}$ \\
\hline HUAP* & $89(29.7)$ & $211(70.3)$ & $300(100.0)$ & \\
PCSA & $17(25.4)$ & $50(74.6)$ & $67(100.0)$ & 0.187 \\
PMF & $5(15.2)$ & $28(84.8)$ & $33(100.0)$ & \\
\hline Total & $\mathbf{1 1 1 ( 2 7 . 8 )}$ & $\mathbf{2 8 9 ( 7 2 . 2 )}$ & $\mathbf{4 0 0 ( 1 0 0 . 0 )}$ &
\end{tabular}

*Reference category; HUAP: Hospital Universitário Antônio Pedro; PCSA: Policlínica Comunitária Sérgio Arouca; PMF: Programa Médico de Família.

consumption of raw and/or undercooked meat, $25.2 \%$ (28/111) with the consumption of vegetables, and $95.5 \%$ (106/111) with contact to feline feces. On the other hand, 26.1\% (29/111) erroneously answered that transmission also occurs by pigeon's feces, and 36.9\% (41/111) that it also occurs by other animals' feces, such as dogs, rabbits, rats and birds. It is noteworthy that $14.4 \%(16 / 111)$ of the women that knew about toxoplasmosis did not know that this disease could be vertically transmitted.

Regarding outcome, $83.8 \%$ of the women did not know the symptoms of toxoplasmosis. Among the women who claimed to know some of the symptoms, fetal malformations and visual impairment were the most cited ones $(11.5 \%[n=46]$ and $11 \%[n=44]$, respectively). Fever, headache and muscular pain were also mentioned.

The lack of knowledge about how to prevent the disease was

Table 3

Description of knowledge about toxoplasmosis prevention from pregnant and postpartum women referred to public health units of Niterói-RJ, Brazil

\begin{tabular}{ccc}
\hline Variables & $\mathbf{n}$ & $\%$ \\
\hline
\end{tabular}

\section{Forms of prevention}

Wash raw foods with clean water.

Wash hands before and after handling food,

48

53

soil and cat litter box.

Not ingest raw or undercooked meat. 50

Use gloves when handling soil or cat litter box.

40

10.0

Feed cats with cat food or well cooked meat.

24

6.0

When pregnant women get infected, she

11.0

should look for medical assistance to avoid

transmission to the baby.

Do not know.

340

85.0

observed in $85 \%(\mathrm{n}=340)$ of the interviews, even in those women who claimed to know about toxoplasmosis (Table 3). Relationship between educational level and the knowledge about toxoplasmosis is demonstrated in Table 4.

\section{DISCUSSION}

The present study demonstrated that $72.2 \%(n=289)$ of the interviewed women had never heard about toxoplasmosis, especially how to prevent it. This condition puts these women in a high risk group, since the lack of information could allow the exposition of pregnant women to $T$. gondii, leading to an acute infection and consequently raising the risks of congenital transmission and even fetal death.

Table 4

Distribution of pregnant and postpartum women referred to public health units of Niterói-RJ, Brazil, according to toxoplasmosis knowledge and schooling, 2010-2011

\begin{tabular}{|c|c|c|c|c|}
\hline Schooling & $\begin{array}{l}\text { Know } \\
\text { n }(\%)\end{array}$ & $\begin{array}{c}\text { Do not know } \\
n(\%)\end{array}$ & $\begin{array}{l}\text { Total } \\
\text { n }(\%)\end{array}$ & $p$ \\
\hline Incomplete fundamental education* & $14(11.9)$ & $104(88.1)$ & $118(100.0)$ & - \\
\hline Complete fundamental education & $07(20.0)$ & $28(80.0)$ & $35(100.0)$ & 0.170 \\
\hline Incomplete medium education & $15(19.5)$ & $62(80.5)$ & $77(100.0)$ & 0.105 \\
\hline Complete medium education & $50(36.2)$ & $88(63.7)$ & $138(100.0)$ & 0.000 \\
\hline Incomplete higher education & $12(70.6)$ & $05(29.4)$ & $17(100.0)$ & 0.000 \\
\hline Complete higher education & $13(86.7)$ & $02(13.3)$ & $15(100.0)$ & 0.000 \\
\hline Total & $111(27.8)$ & $289(72.2)$ & $400(100.0)$ & \\
\hline
\end{tabular}

${ }^{*}$ Reference category. 


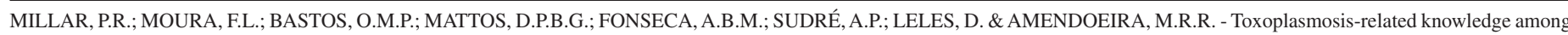
pregnant and postpartum women attended in public health units in Niterói, Rio de Janeiro, Brazil. Rev. Inst. Med. Trop. Sao Paulo, 56(5): 433-8, 2014.

Amongst women who did not know about toxoplasmosis, $180(62.3 \%)$ were reactive.

Previous studies have already reported the unawareness of pregnant and postpartum women about this zoonosis in other regions of Brazil. In Mato Grosso ${ }^{23}, 78 \%$ of the participant women did not know about toxoplasmosis. In Rio Grande do $\mathrm{Sul}^{8}$ and Minas Gerais ${ }^{18}$, 64.9\% and $93 \%$ of the pregnant women had never heard about this disease, respectively. In Paraná ${ }^{4}$, only $16.2 \%$ of the pregnant women received information regarding toxoplasmosis prevention during prenatal care. In a study conducted in the United States ${ }^{22}, 61 \%$ of the pregnant women knew that $T$. gondii is eliminated in the feces of infected cats, however, only $30 \%$ knew that the protozoa can be transmitted by raw or undercooked meat, and $29 \%$ knew that it can be transmitted by practicing gardening without gloves. In the present study, 95.5\% (106/111) of the women who claimed to know about toxoplasmosis were aware that transmission can occur by infected cat's feces, $36.9 \%$ (41/111) knew that transmission can occur by raw or undercooked meat and $25.2 \%(28 / 111)$ by poorly washed vegetables.

The amount of people who knew the risk factors associated with $T$. gondii infection was very low in the studied population. Consequently, hygienic and dietary habits that could avoid the infection during pregnancy are not adopted, putting the fetus's health at risk. Moreover, there are many misconceptions regarding T. gondii transmission produced by the local press or schools that could be clarified by well-informed health agents. For example, it is possible for pregnant women to have cats in their homes, provided that hygienic habits are kept and there is no direct contact with cat's feces. An additional misunderstanding was that toxoplasmosis could be transmitted by dog's or pigeon's feces.

Another important finding of this study is that $83.8 \%$ of the participating women did not know the symptoms of toxoplasmosis. Although toxoplasmosis in pregnancy is asymptomatic in most cases, this is a very critical point, because recognizing the symptoms (when they are present) can be helpful for an early diagnosis during pregnancy. Moreover, these symptoms are severe in children and can cause permanent sequelae, such as ocular lesion or even death.

According to Table 4, educational level and the percentage of women who claimed to know the disease are directly related. In this regard, educational level is a protection factor against $T$. gondii infection.

The present results reflect the situation observed in the prenatal care of public health institutes of Niterói, which is similar to what is found in other Brazilian cities. Primary prevention actions to avoid exposure to $T$. gondii and other infectious agents are not performed during prenatal care, such as meeting groups to exchange information and experiences, as well as orientation by a health agent. Information during prenatal care contributed to a $63 \%$ reduction in $T$. gondii first infection during pregnancy ${ }^{19}$. A study in Canada ${ }^{30}$ highlighted the importance of education to prevent toxoplasmosis during prenatal care.

In Londrina, Paraná, after the implementation of a congenital toxoplasmosis control program, it was observed a $63 \%$ reduction in the number of infected pregnant women and a $42 \%$ reduction in the number of children forwarded to reference services. The definition of the protocols resulted in standardized assistance procedures and greater safety for decision-making by the doctors ${ }^{24}$.

Another study in 2006 with pregnant teenagers in Ceará also highlighted the importance of preventive actions for toxoplasmosis during pregnancy ${ }^{9}$. In order to evaluate the toxoplasmosis-related knowledge of doctors and nurses, a study was conducted in Juiz de Fora, Minas Gerais. Only 44\% of the answers were correct, and most of the incorrect answers were related to prevention and diagnosis. These results demonstrated the lack of interest and information update by health agents ${ }^{33}$.

Health agents need to be well-informed and capable to give correct information to the patients; otherwise, all care will be compromised. The high rate of unawareness about toxoplasmosis (72.2\%), observed in the present study, indirectly reflects the assistance quality provided by the health agents to the patients during prenatal care. These findings become more important with the results obtained by MOURA et al. $(2013)^{29}$ in the same region, which observed that $41.5 \%(166 / 400)$ of pregnant and postpartum women were susceptible to $T$. gondii infection. In Niterói, there is no program to control congenital toxoplasmosis. This situation can make the health agents insecure to correctly inform their patients, since they will have to get information by themselves, i.e., without the help of specialized professionals.

Primary prevention actions against congenital toxoplasmosis during prenatal care is a national need, since the results observed in the city where the study was conducted are similar to those observed in other Brazilian cities.

The lack of knowledge about the disease observed in most of the interviewed population indicates that a large number of women are susceptible to T.gondii infection during pregnancy. These susceptible women can transmit the protozoa to their offspring, leading to severe sequelae and even death. These results highlight the importance of serological screening programs, as well as primary prevention by providing correct information during prenatal care. Guidelines for women who intend to get pregnant are also important in reducing the occurrence of congenital toxoplasmosis.

\section{RESUMO}

\section{Conhecimento sobre toxoplasmose entre gestantes e puérperas atendidas na rede pública de saúde do município de Niterói, Rio de Janeiro, Brasil}

Este estudo teve por objetivo realizar um levantamento do conhecimento de 400 gestantes e puérperas atendidas na rede pública de saúde do município de Niterói, Estado do Rio de Janeiro sobre a toxoplasmose. Apenas $111(27,8 \%)$ participantes relataram conhecer a doença. A maioria $289(72,2 \%)$ nunca ouviu falar sobre a toxoplasmose, principalmente sobre as formas de prevenção da infecção pelo Toxoplasma gondii. Foi encontrada diferença significativa entre as pacientes que disseram conhecer a toxoplasmose e aquelas que relataram desconhecer a doença com relação à presença de anticorpos IgG anti- T.gondii $(p=0,013)$. Estes resultados permitem ressaltar a importância do rastreamento sorológico sistemático na infecção 
MILLAR, P.R.; MOURA, F.L.; BASTOS, O.M.P.; MATTOS, D.P.B.G.; FONSECA, A.B.M.; SUDRÉ, A.P.; LELES, D. \& AMENDOEIRA, M.R.R. - Toxoplasmosis-related knowledge among pregnant and postpartum women attended in public health units in Niterói, Rio de Janeiro, Brazil. Rev. Inst. Med. Trop. Sao Paulo, 56(5): 433-8, 2014.

toxoplásmica, bem como a prevenção primária por meio de informações corretas durante o pré-natal, sendo esta uma importante medida de saúde pública a ser implementada.

\section{ACKNOWLEDGEMENTS}

CAPES, Laboratório de Toxoplasmose (LABToxo) of Instituto Oswaldo Cruz (IOC/Fiocruz), Instituto de Pesquisas Clínicas Evandro Chagas, Fiocruz and Universidade Federal Fluminense.

\section{REFERENCES}

1. Ambroise-Thomas P. Toxoplasmose congénitale: les différentes stratégies préventives Arch Pediatr. 2003;10(Suppl 1):12-4.

2. Avelino MM, Campos D Jr, Parada JB, Castro AM. Risk factors for Toxoplasma gondii infection in women of childbearing age. Braz J Infect Dis. 2004;8:164-74.

3. Bahia-Oliveira LMG, Jones JL, Azevedo-Silva J, Alves CCF, Oréfice F, Addiss DG. Highly endemic, waterborne toxoplasmosis in north Rio de Janeiro State, Brazil. Emerg Infect Dis. 2003;9:55-62.

4. Branco BHM, de Araújo SM, Falavigna-Guilherme AL. Prevenção primária da toxoplasmose: conhecimento e atitudes de profissionais de saúde e gestantes do serviço público de Maringá, estado do Paraná. Scienc Med. 2012;22:185-90.

5. Brasil. Ministério da Saúde. Manual técnico pré-natal e puerpério: atenção qualificada e humanizada. Brasília: Departamento de Ações Programáticas e Estratégicas/ Ministério da Saúde; 2005 (Série A. Normas e manuais técnicos, Série Direitos sexuais e direitos reprodutivos - caderno $n^{\circ}$ 5). ISBN 85-334-0885-4.

6. Bonametti AM, Passos J do N, da Silva EM, Bortoliero AL. Surto de toxoplasmose aguda transmitida através de ingestão de carne crua de gado ovino. Rev Soc Bras Med Trop. 1997;30:21-5

7. Bowie WR, King AS, Werker DH, Isaac-Renton JL, Bell A, Eng SB, et al. Outbreak of toxoplasmosis associated with municipal drinking water. The BC Toxoplasma Investigation Team. Lancet. 1997;350(9072):173-7.

8. Cademartori BG, Farias NAR, Brod CS. Soroprevalência e fatores de risco à infecção por Toxoplasma gondii em gestantes de Pelotas, Sul do Brasil. Rev Panam Infect. 2008;10:30-5

9. Costa FF, Gondim AP, de Lima MB, Braga JU, Vieira LJ, Araújo MA. Preventive behavior for toxoplasmosis in pregnant adolescentes in the state of Ceara, Brazil. BMC Public Health. 2012;12:73.

10. Coutinho SG, Lobo R, Dutra G. Isolation of Toxoplasma from soil during an outbreak of toxoplasmosis in a rural area in Brazil. J Parasitol. 1982;68:866-8.

11. Coutinho SG, Garcia AP, Amendoeira MRR, Assumpção MR, Albano N. Detection of newborn infants at risk for congenital toxoplasmosis in Rio de Janeiro, Brazil. Rev Inst Med Trop Sao Paulo. 1983;25:25-30.

12. Demar M, Azenberg D, Maubon D, Djossou F, Panchoe D, Punwasi W, et al. Fatal outbreak of human toxoplasmosis along the Maroni River: epidemiological, clinical, and parasitological aspects. Clin Infect Dis. 2007;45:e88-95.

13. Detanico L, Basso RMC. Toxoplasmose: perfil sorológico de mulheres em idade fértil e gestantes. Rev Bras Anál Clín. 2006;38:15-8.

14. Dubey JP, Lago EG, Gennari SM, Su C, Jones JL. Toxoplasmosis in humans and animals in Brazil: high prevalence, high burden of disease, and epidemiology. Parasitology. 2012;139:1375-424.

15. Dumètre A, Dardé ML. How to detect Toxoplasma gondii oocysts in environmental samples? FEMS Microbiol Rev. 2003;27:651-61.
16. Elbez-Rubinstein A, Ajzenberg D, Dardé ML, Cohen R, Dumètre A, Yera H, et al. Congenital toxoplasmosis and reinfection during pregnancy: case report, strain characterization, experimental model of reinfection, and review. J Infect Dis. 2009; 199:280-5.

17. Figueiró- Filho EA, Lopes AHA, Senefonte FRA, Souza Júnior VG, Botelho CA, et al. Toxoplasmose aguda: estudo da frequência, taxa de transmissão vertical e relação entre os testes diagnósticos materno-fetais em gestantes em Estado da Região Centro-Oeste do Brasil. Rev Bras Ginecol Obstet. 2005; 27:442-9.

18. Fonseca AL, Silva RA, Fux B, Madureira AP, Sousa FF, Margonari C. Epidemiologic aspects of toxoplasmosis and evaluation of its seroprevalence in pregnant women. Rev Soc Bras Med Trop. 2012;45:357-64.

19. Foulon W. Congenital toxoplasmosis: is screening desirable? Scand J Infect Dis. 1992;84(Suppl):11-7.

20. Gavinet MF, Robert F, Firtion G, Delouvrier E, Hennequin C, Mawrin JR, et al. Congenital toxoplasmosis due to maternal reinfection during pregnancy. J Clin Microbiol. 1997;35:1276-7.

21. Jones JL, Lopez A, Wilson M, Schulkin J, Gibbs R. Congenital toxoplasmosis: a review. Obstet Gynecol Surv. 2001;56:296-305.

22. Jones J, Lopez A, Wilson M. Congenital toxoplasmosis. Am Fam Physician. 2003;67:2131-8.

23. Leão PRD, Meirelles Filho J, Medeiros SF. Toxoplasmose: soroprevalência em puérperas atendidas pelo Sistema Único de Saúde. Rev Bras Ginecol Obstet. 2004;26:627-32.

24. Lopes-Mori FMR, Mitsuka-Breganó R, Capobiango JD, Inoue IT, Reiche EMV, Morimoto HK, et al. Programas de controle da toxoplasmose congênita. Rev Assoc Med Bras. 2011;57:594-9.

25. Magaldi C, Elkis H, Pattoli D, de Queiróz JC, Coscina AL, Ferreira JM. Surto de toxoplasmose em um seminário de Bragança Paulista (Estado de São Paulo): aspectos clínicos, sorológicos e epidemiológicos. Rev Saude Publica. 1967;1:14171.

26. Magorzata P, Petersen E, Szczapa J. Prevalence of congenital Toxoplasma gondii infection among newborns from the Pozna Region of Poland: validation of a new combined enzyme immunoassay for Toxoplasma gondii specific immunoglobulin A and immunoglobulin M antibodies. J Clin Microbiol. 2001;39:1912-6.

27. Montoya JG, Liesenfeld O. Toxoplasmosis. Lancet. 2004;363(9425):1965-76.

28. Montoya JG, Rosso F. Diagnosis and management of toxoplasmosis. Clin Perinatol. 2005;32:705-26.

29. Moura FL, Amendoeira MRR, Bastos OMP, Mattos DPBG de, Fonseca ABM, Nicolau $\mathrm{JL}$, et al. Prevalence and risk factors for Toxoplasma gondii infection among pregnant and postpartum women attended at public healthcare facilities in the City of Niterói, State of Rio de Janeiro, Brazil. Rev Soc Bras Med Trop. 2013;46:200-7.

30. Paquet C, Yudin MH. Toxoplasmosis in pregnancy: prevention, screening, and treatment. J Obstet Gynaecol Can. 2013;35:78-9.

31. Pawlowski ZS, Gromadecka-Sutkiewicz M, Skommer J, Paul M, Rokossowski H, Suchocka E, et al. Impact of health education on knowledge and prevention behavior for congenital toxoplasmosis: the experience in Poznan, Poland. Health Educ Res. 2001; 16:493-502.

32. Remington JS, McLeod R, Wilson CB, Desmonts G. Toxoplasmosis. In: Remington JS, Klein JO, editors. Infectious diseases of the fetus and newborn infant. $7^{\text {th }}$ ed. Pennsylvania: Elsevier; 2010. p. 918-1041.

33. Silva LB, Oliveira RVC, Silva MP, Bueno WF, Amendoeira MRR, Neves ES. Knowledge of toxoplasmosis among doctors and nurses who provide prenatal care in an endemic region. Infect Dis Obstet Gynecol. 2011;2011:750484. doi: 10.1155/2011/750484. 
MILLAR, P.R.; MOURA, F.L.; BASTOS, O.M.P.; MATTOS, D.P.B.G.; FONSECA, A.B.M.; SUDRÉ, A.P.; LELES, D. \& AMENDOEIRA, M.R.R. - Toxoplasmosis-related knowledge among pregnant and postpartum women attended in public health units in Niterói, Rio de Janeiro, Brazil. Rev. Inst. Med. Trop. Sao Paulo, 56(5): 433-8, 2014.

34. Souza WJ, Coutinho SG, Lopes CW, dos Santos CS, Neves NM, Cruz AM. Epidemiological aspects of toxoplasmosis in schoolchildren residing in localities with urban or rural characteristics within the city of Rio de Janeiro, Brazil. Mem Inst Oswaldo Cruz. 1987;82:475-82.

35. SYROCOT (Systematic Review on Congenital Toxoplasmosis) study group, Thiebaut RS, Leproust S, Chêne G, Glibert R. Effectiveness of prenatal treatment for congenital toxoplamosis: a meta-analysis of individual patients data. Lancet. 2007;369(9556):115-22.
36. Wallon M, Peyron F, Cornu C, Vinault S, Abrahamowicz M, Kopp CB, et al. Congenital toxoplasma infection: monthly prenatal screening decreases transmission rate and improves clinical outcome at age 3 years. Clin Infect Dis. 2013;56:1223-31.

37. Wilson CB, Remington JS. Toxoplasmosis. In: Feigin RD, Cherry JD. Textbook of pediatric infectious diseases. 3 ed. Philadelphia: Saunders; 1992. p. 2057-69.

Received: 11 September 2013

Accepted: 20 February 2014 